\title{
EFFECT OF SEED DETERIORATION, SEED DRESSING AGENTS AND SEED VIGOUR PARAMETERS IN MAIZE (ZEA MAYS L.) HYBRIDS
}

\author{
T.Berzy $^{1}$, S. Zaborszky ${ }^{2}$, C. L. Marton ${ }^{1}$, T. Spitko, J. Pinter ${ }^{1}$, Z. Toth-Zsubori ${ }^{1}$, C. Szoke ${ }^{1}$ \\ ${ }^{1}$ Agricultural Research Centre,2462 Martonvásár, Hungary \\ ${ }^{2}$ University of Pannonia, 8360 Keszthely, Hungary \\ https://doi.org/10.35410/IJAEB.2020.5492
}

\begin{abstract}
Seed dressing agents could limit the number of abnormal or low vigorous seedlings.In the case of emergence time, the percentage of emerged plants depended to the greatest extent on the genotype, butseeddressingalsocouldsubstantialeffectontheemergencepercentage. In spring 2019 ,seed lots of seven maizegeno types, - which had been stored for various lengths of time - were studied in laboratory and field experiments (in Martonvásár and Keszthely).The seedling root weight were consistently and significantly higher in case of seed dressing with fludioxonil and metalaxyl-Mfungicides,than seed dressing with fludioxonil+tiabendazol+metalaxil$\mathrm{M}+$ azoxistrob in fungicides.After five years seed storing, the ratio of non-germinated seed swas significant higher in case of all hybrids. The highest seed storing period eliminating the seedling emergence and kernel yield.The importance of the maternal crossing combination effect could be enormous,- be side the seed storing time.Correlations between the seed vigour, fresh shoot weight, fresh root weight and kernel yield are close-in case of Mv 06 hybrid-corn.
\end{abstract}

Keywords: Seed Dressing, Seed vigour, Storing time.

\section{INTRODUCTION}

The use of satisfactory storage conditions may help to lengthen the lifespan, while storage under suboptimal conditions may lead to a substantial reduction in the genetic potential or vigour of the seeds (Berzy et al., 2007; Marcos-Filho, 2015; Berzy et al. 2017). Following ripening and afterripening, aging processes begin in the seeds, as the result of which there is a gradual decline in viability. High temperature and atmospheric moisture lead to an acceleration in respiration, thus promoting aging. The reduction in the vigour of aging seeds is indicated by the fact that they have a higher temperature requirement for germination than young seed lots. The germination vigour declines, while the germination time is lengthened (Blacklow, 1972; Marton and Szundy, 1997; Lovato et al., 2001; Mavi et al., 2010; Matsushima and Sakagami, 2013). There may also be changes in the size and weight of the seedlings. The aim is thus to create storage conditions that inhibit respiration and the decomposition of nutrient reserves. As storage is primarily designed to preserve seeds as a source of germplasm, or hereditary material, only mature, undamaged seeds can be stored for any length of time (Goodsell et al., 1955; Tang et al., 2000; FAO, 2018). Injuries to the seed-coat have a negative effect on the physiological processes of the seed, which can be more easily attacked by bacteria and fungi, leading to the development of abnormal seedlings. Under stress conditions these abnormal seedlings (twisted stem, cracked 
hypocotyl) may not survive (Fessel, et al. 2001). In the course of aging the seed may darken and the seed-coat may shrink. These changes chiefly affect the cell membranes, which serve to protect the nutrient reserves of the cells (Matthews and Bradnock, 1968; Barnabás et al., 2008).

The aging process may differ with the genotype. It depends on the seed-coat structure, the size of the nutrient reserves and the storage conditions. If the metabolism (respiration) is retarded during storage, it is possible to prevent the rapid decline in germination ability. In the case of maize, storage temperatures above $43^{\circ} \mathrm{C}$ or below freezing point may cause a considerable reduction in germination ability (in the case of $12-13 \%$ grain moisture content). If the storage time is longer than a year, it is advisable to maintain a storage temperature of $21^{\circ} \mathrm{C}$ with $55 \%$ relative humidity $(\mathrm{RH})$. The microorganisms present on the seed surface are capable of multiplying even at $4-$ $10^{\circ} \mathrm{C}$ and at $\mathrm{RH}$ values of $65-70 \%$. A grain moisture content higher than $14 \%$ is also favourable for the activity of insect pests (Christeller, 1984;Deuner et al., 2014; Dansoetal., 2017).

Effect of seed size and genotype on the laboratory and field emergence could be different in case of grain and sweet corn (Gubbels, 1974; Bennett et al. 1988).

If storage losses are to be kept to a minimum, chilled storage is advisable, at a temperature of 4$5^{\circ} \mathrm{C}$ with a humidity of $45-50 \%$. If the moisture content of the stored seed is below $11-12 \%$, the seed may retain its viability under such conditions for years.

Different seed dressing agents could limit the number of abnormal or low vigorous seedlings .Záborszky et al. (2002) four inbred lines with different levels of chilling tolerance were studied in the experiments. The seeds of these lines were treated with three different dressing agents (TMTD WP, Carboxin + TMTD, TMTD FS, with an untreated control) and the seeds were sown in two types of soil: 1 . infected maize soil; 2 . heat-sterilised soil (control).It was found that of the three factors tested, the number of days to emergence was only influenced by the genotype. None of the interactions caused a significant modification of the emergence time.As in the case of emergence time, the percentage of emerged plants depended to the greatest extent on the genotype, but seed dressing also had a substantial effect on the emergence percentage. The emergence percentage was significantly increased by the seed treatments compared to the undressed control, however the dressing agents was not statistically significant.

The object this experiment, determine the best seed amounts, point of view the seed vigour, seed emergence, and yielding ability.

\section{MATERIALS AND METHODS}

In spring 2019, seed lots of seven maize genotypes (the hybrids MV01, MV02, MV03,MV04, MV05, MV06, and MV07), which had been stored for various lengths of time $\left(10{ }^{\circ} \mathrm{C}, 60 \% \mathrm{RH}\right.$ storing), were studied in laboratory and field experiments (in Martonvásár and Keszthely).

The seed amounts in every hybrid- except, MV06, MV07 - were divided two parts:

1. Seed treating with fludioxonil +metalaxil-M(A type) anddoses of the seed dressing were 1 $\mathrm{ml} / \mathrm{kg}$ seed. 
2. Seed treating with fludioxonil, tiabendazol, metalaxil-M, azoxistrobin (B type)and doses of the seed dressing were $1 \mathrm{ml} / \mathrm{kg}$ seed.

\section{Laboratory experiments}

\section{Germination ability}

After preliminary and basic cleaning, the seeds were divided into fractions and germinated according to the Hungarian standard (MSZ 6354/3-82) between layers of crepe filter paper moistened with 1.6-1.7 g water per g paper. Four rolls, each containing 50 evenly distributed seeds, were placed vertically in each of two plastic bags and kept in a Fito-Klima germination chamber at $25^{\circ} \mathrm{C}$ and $70 \% \mathrm{RH}$ for seven days.

\section{Complex stressing vigour test (CSVT)}

During the first 96 hours of the test, the seeds $(8 \times 25)$ were exposed to a combination of stress factors that may occurin nature in the case of unfavourable weather conditions in spring (hypoxia and cold stress) and that represent complex stress for the seedlings (Barla-Szabó and Berzy, 1989). The stress period was followed by 96 hours germination. The developing seedlings were divided on the basis of shoot length into high- and low-vigour groups, or were classified as abnormal or non-germinated.

\section{Field experiments}

The experiments were carried out in the nursery of the Georgikon Faculty, University of Pannonia, in Keszthely, and Martonvásár. The soil was a Ramann's brown forest soil with sandy loam texture and low humus content $(1.65 \%)$, with a $\mathrm{pH}\left(\mathrm{H}_{2} \mathrm{O}\right)$ value of 6.3 , slightly increasing with depth. The soil was moderately well supplied with phosphorus $\left(\mathrm{P}_{2} \mathrm{O}_{5}=130 \mathrm{ppm}\right)$, poorly supplied with potassium $\left(\mathrm{K}_{2} \mathrm{O}=50 \mathrm{ppm}\right)$, and had good water permeability.

The genotypes were sown in a split-plot design in four replications, with the maize genotypes in the main plots and the treatments (A. two-component seed dressing chemical, B.four-component seed dressing chemical) in the subplots. The plots measured $2.25 \times 6 \mathrm{~m}$, with two rows of 30 plants per plot.

Sowing was carried out with a hand-held seed drill on 26 ofApril. Records were made of the number of plants emerging, the dates of 50\% tasselling and silking, the grain moisture content at harvest (Grainer, Japan), the appearance of the black layer, and stalk lodging.

The plants were harvested manually on 10 October. The fresh ear yield was weighed, and the kernel yield was recorded after drying at $38^{\circ} \mathrm{C}$ and shelling. Due to the diverse grain moisture contents of the genotypes, the results were converted to $14 \%$ moisture content and the data were evaluated using single- and two-factor analysis of variance (Sváb, 1981).

\section{RESULTS}

\section{Seed vigourand hybrids}


An analysis of the effect of genotype on the characters tested shows that the order of the hybrids was not the same for ratio of high vigour seedlings and 8 days old seedlings fresh weight. The ratio of high vigour seedlings, and 8 days old seedlings fresh weight were the best in case of MV01 and MV05 hybrids. The seedling fresh weight results also indicated the highest biological value of MV01 hybrid (Table1).

It is significantly proven that the longest storage time decreases both the root length, the percentage emergence and the yield, but increases the ratio of non-germinated (rotten) seeds and the number of days BBCH14 stage (Table 5).

The complex stressing vigour test results obtains for seed lots of the grain maize hybrid MV06 stored for six years dropped to half, and the vigour determined to a third of the values recorded after four years of storage (Table 2). This was confirmed by both the shoot and root weight measurements and the grain yields (Table 2 and Table 3). The biological value of seeds of MV06 was thus found to be drastically reduced by storage for more than five years.

The seedling root weight were consistently and significantly higher in case of seed dressing with A type (fludioxonil and metalaxil-M), than the seed dressing with B type (fludioxonil+tiabendazol+metalaxil-M+azoxistrobin)fungicides(Table 2).

\section{Seed dressing and kernel yield}

Despite the less vigouros and stress sensitive seedlings of seed amounts ofhybrid MV05 (2-yearold, 2017 seeds), had better emergenceand significantly higher kernel yield in Keszthely- in case of fludioxonil and metalaxil-M seed dressing(Table 3).

The sowing time and weather conditions were optimal for the seedlings, the germination ability could be more important, than the seed vigour.

There was not differences between the seed dressings at MV02, and MV03.

Thebest hybrid results mainly experimented in case of the shortest, or middle short storing period - irrespective of genotypes(Table 5).

\section{Seed storing and seed dressing, kernel yield}

Despite the less vigorous and short storing( 2 years) seed amounts of hybrid MV05, had better emergence and kernel yield,- because of the excellent germination ability. The seedling emergence effect was significant for kernel yield - in case of experimental field conditions at Keszthely .(Table 2 and Table 3) There wasno difference between the seed amounts during optimal environmental conditions. Reciprocal crossing type seed amounts of 3-year-old MV05 hybrid ( seed dressing " $\mathrm{A}$ " type) were more sensible for the seedling emergence- during suboptimal weather conditions.

The highest seed storing period ( 8 years) caused significant eliminating the seedling emergence and kernel yield - in case of hybrid MV04 (Table 2 and Table 3). 
Seed biological value of six years old storing seed amounts were worst, -compared with 7- and 3 -year-old seed storing. The moderate eliminating at seed vigour (67\%) could cause the lowest kernel yield in case of hybrid MV02.

The reciprocal crossing type seed amounts -at MV03 hybrid - had similar sensibility at seed vigour, like hybrid MV05.

The maternal effect for seedling sensibility for suboptimal emergence conditions of H68 line(MV03) similar to the H71(MV05) line. We emphasize the importance of reciprocal maternal crossing combinations effect, - beside the seed storing time.

The moderate seedling vigour and seedling weight could cause poor emergence and significant low kernel yield (Table 2, Table 3).

A close correlation was found between the vigour of stressed seedlings (CSVT) and the grain yield for highest stress sensible hybrid MV06 $\left(r^{2}=0.805\right)$.

The correlation between fresh shoot weight (SW) and the grain yield was also obviousfor MV06, and MV07 $\left(r^{2}=0.840\right.$ and 0.660 , respectively), while the correlation between the fresh root weight $(\mathrm{RW})$ and kernel yield was enormous in case ofMV06 $\left(\mathrm{r}^{2}=0.830\right)$.

The following equations were obtained from linear regression analysis between the kernel yield $\left(\mathrm{Y}^{\prime}\right)$ and the seedling parameters.

$$
\begin{aligned}
& Y^{\prime}=6.32+0.017 \mathrm{CSVT}(\mathrm{MV} 06) \\
& \mathrm{Y}^{\prime}=11.40+0,750 \mathrm{SW}(\mathrm{MV06}, \mathrm{MV} 07) \\
& \mathrm{Y}^{\prime}=11.63+1.190 \mathrm{RW}(\mathrm{MV06}) .
\end{aligned}
$$

\section{CONCLUSIONS}

After five years seed storing, the ratio of non-germinated seeds was significant higher in case of all hybrids. The highest seed storing period eliminating the seedling emergence and kernel yield.

The seedling root weight were consistently and significantly higher in case of seed dressing with fludioxonil + metalaxil-M.

The moderate seedling vigour and seedling weight could cause poor emergence and low kernel yield in case of suboptimal environmental conditions (MV04).

The importance of the maternal crossing combination effect could be enormous, - beside the seed storing time.

The highest stress sensible hybrid for more than 5 years seed storing is: MV06. Correlations between the seed vigour, fresh shoot weight, fresh root weight and kernel yield are close - in case of MV06. 
Vol. 5, No. 02; 2020

ISSN: $2456-8643$

\section{REFERENCES}

Barla-Szabó,G., Berzy T.(1989): Application of Seed Vigour Tests for Corn Production Georgikon for Agriculture, 2:159-165.

Barnabás B., Jager K., Fehér A (2008): The effect of drought and heat stress on reproductive processes in cereals. Plant, Cell and Environment, 31:11-38.

Bennett, M. A., Waters, L., Jr.Curme J. H. (1988): Kernel maturity, seed size, and seedhydratation effect on sweet corn inbred. J.Amer.Hort.Sci.113:348-353.

Berzy,T., Hegyi,Z., Pintér,J.(2007): Correlations between the seed quality and yieldparameters of maize hybrids developed on diverse parental lines.In: 28 th ISTA Seed Symposium, Abstract, Iguassu Falls, May 7-9. Brasil, 95 p.

Berzy T., Záborszky S., Pintér J. (2017):Reciprok keresztezésű hibridkukorica vetőmagelőállítás, vetőmag vigor és termőképesség.In: XXIII Növénynemesítési Tudományos Nap, 2017.március 7. MTA,Budapest, Hungary, 86 p.

Blacklow, W.M.(1972): Influence of temperature and germination and elongation ofthe radicle and shoot of corn (Zea mays L.).Crop Science, 28:801-805.

Christeller, J.I.(1984): Seedling growth of Zea mays at $13{ }^{\circ} \mathrm{C}$. Comparison of CornBelt Dent Hybrid and hybrid selected for rapid plumula emergence at cool temperatures.J.Exp.Bot.35. 955-964.

Danso J. K., Osekre E. A., Manu N., Opit G. P., Armstrong P., Arthur F. H., Campbell J. F., Mbata G. (2017): Moisture content, insect pests and mycotoxin levels of maize at harvest and post-harvest in the Middle Belt of Ghana. Journal of Stored Products Research 74:46-55.

Deuner, C., Rosa, C. K., Meneghello, E. G., Borges, T. C., Almeida, S. A., Bohn, A. (2014): Physiological performance during storage of corn seed treated with insecticides and fungicide. Journal of Seed Science, 36:204-212.

FAO (2018): Seeds toolkit - Module 6: Seed storage. Rome, 112 pp.

Fessel,S.A., Roberwald,D., Cruz Vieria and Mara C.P.(2001):Evaluation of seedtreatment effect on crop establishment using a model simulating plant emergence.In: 26th ISTA Seed Symposium, Abstract, Angers, $74 \mathrm{p}$.

Goodsell,S.F., Huey G., Royce, R. (1955): The effects of moisture and temperature duringstorage and cold test reaction of Zea mays seed storage in air, carbon dioxide andnitrogen.Agronomy Journal47:61-64.

Gubbels ,G.H.(1974): Effect of seed size on emergence, grain yield, and plant height incorn.Canadian Journal of Plant Science, 54:252-256. 
Lovato,A.,Noli,E., Beltrami,E., Grassi,E.(2001): Comparison between three cold test low temperatures, accelerated aging test and field emergence of maize seed. In: 26 th ISTA Seed Symposiumm, Abstract, Angers, $47 \mathrm{p}$.

Marcos-Filho, J. (2015): Seed vigor testing: an overview of the past, present and future perspective. Scientia Agricola, 72:363-374.

Martin,B.A., Smith,O.S., O' Neil,M.(1988): Relationship between laboratorygermination test and field emergence of maize inbreds. Crop Science, 28:801-805.

Marton, L. C. and Szundy, T. (1997): Development of young maize plants under a suboptimal range of temperatures. Acta Agronomica Hungarica, 45:329-335.

Mathews,S., Bradnock,W.T.(1968): Relationship between seed exudation and fieldemergence in peas and French beans. Hort.Res.,8:89-93.

Matsushima K. I., Sakagami J. I. (2013):Effects of Seed Hydropriming on Germination and Seedling Vigor during Emergence of Rice under Different Soil Moisture Conditions. American Journal of Plant Sciences, 4:1584-1593.

Mavi K., Demir, I. and Matthews, S. (2010):Mean germination time estimates the relative emergence of seed lots of three cucurbit crops under stress conditions. Seed Sci. \& Technol., $38: 14-25$.

Sváb, J. (1981): Biometriai módszerek a mezőgazdasági kutatásban. (Biometrical Methods in Agricultural Research.) Mezőgazdasági Kiadó, Budapest, 490 p.

Tang,S., TeKrony,D.M., Egli,D.B., Cornelis,P.L.(2000): An Alternative Model to Predict Corn Seed Deterioration during Storing. Crop Science,40:463-470.

Záborszky S., Nagy E., Szöke C. (2002): Effect of seed treatment on the emergence of inbred lines of maize (Zea mays L.) Acta Agronomica Hungarica, 50:359-369. 
International Journal of Agriculture, Environment and Bioresearch

Vol. 5, No. 02; 2020

ISSN: $2456-8643$

Table 1. Effect of genotype on the characters examined, averaged over seed dressing and storage time (Martonvásár, 2019)

\begin{tabular}{|l|c|c|c|}
\hline \multicolumn{1}{|c|}{ Genotypes } & Hight vigour $(\boldsymbol{p c})$ & Rotten seeds $(\boldsymbol{p c})$ & $\begin{array}{c}\text { Seedling fresh } \\
\text { weight }(\boldsymbol{g})\end{array}$ \\
\hline MV01 & 17.25 & 3.71 & 1.95 \\
MV02 & 13.33 & 6.17 & 1.56 \\
MV03 & 16.54 & 4.08 & 1.21 \\
MV04 & 12.75 & 6.33 & 0.87 \\
MV05 & 17.71 & 2.71 & 1.83 \\
\hline LSD 5\% $^{2.33 * * *}$ & $1.25^{* * *}$ & $0.32^{* * *}$ \\
\hline
\end{tabular}

Table 2. Seed biological value, seed storing and seed dressing (Atype=fludioxonil+metalaxil-M, B type=fludioxonil+tiabendazol+metalaxilM+azoxistrobin) (Martonvásár, 2019)

\begin{tabular}{|c|c|c|c|c|c|c|c|c|c|c|c|c|c|c|c|c|}
\hline \multirow{2}{*}{ Hybrid } & \multirow{2}{*}{$\begin{array}{c}\text { Crossing } \\
\text { combination }\end{array}$} & \multirow{2}{*}{$\begin{array}{c}\text { Storing } \\
\text { year }\end{array}$} & \multicolumn{2}{|c|}{ Germination (\%) } & \multicolumn{2}{|c|}{$\begin{array}{l}\text { Vigour } \\
(\%)\end{array}$} & \multicolumn{2}{|c|}{ Emergence (\%) } & \multicolumn{2}{|c|}{$\begin{array}{l}\text { Germination } \\
\text { weight }(\mathrm{g})\end{array}$} & \multicolumn{2}{|c|}{$\begin{array}{l}\text { Root weight } \\
\text { (g) }\end{array}$} & \multicolumn{2}{|c|}{$\begin{array}{l}\text { Germination lenght } \\
(\mathrm{cm})\end{array}$} & \multicolumn{2}{|c|}{$\begin{array}{l}\text { Root lenght } \\
\quad(\mathrm{cm})\end{array}$} \\
\hline & & & A type & B type & A type & B type & A type & B type & A type & B type & A type & B type & A type & B type & A type & B type \\
\hline MV01 & Direct & 2013 & 95.00 & 96.00 & 96.00 & 80,00 & 81.50 & 95.75 & 7.04 & 3.85 & 5.88 & 3.09 & 10.10 & 7.45 & 12.80 & 7.58 \\
\hline MV01 & Direct & 2015 & 96.00 & 97.00 & 93.00 & 90,00 & 79.50 & 90.50 & 6.16 & 0.65 & 5.31 & 0.59 & 11.00 & 3.06 & 12.80 & 6.88 \\
\hline MV02 & Direct & 2012 & 90.00 & 90.00 & 73.00 & 66,00 & 73.25 & 84.75 & 5.00 & 0.79 & 5.04 & 0.91 & 7.50 & 2.00 & 11.50 & 4.51 \\
\hline MV02 & Direct & 2013 & 90.00 & 91.00 & 67.00 & 73,00 & 79.00 & 88.50 & 4.32 & 1.78 & 4.41 & 1.80 & 7.50 & 4.15 & 11.70 & 7.50 \\
\hline MV02 & Direct & 2015 & 91.00 & 91.00 & 79.00 & 79,00 & 86.75 & 76.75 & 5.02 & 2.10 & 4.62 & 1.47 & 8.25 & 5.69 & 11.20 & 9.94 \\
\hline MV03 & Direct & 2013 & 94.00 & 94.00 & 91.00 & 77,00 & 99.25 & 91.75 & 6.20 & 1.56 & 6.35 & 1.18 & 9.50 & 5.59 & 11.30 & 9.34 \\
\hline MV03 & Reciprocal & 2016 & 92.00 & 93.00 & 84.00 & 74,00 & 78.50 & 87.00 & 4.80 & 0.91 & 6.52 & 0.74 & 8.25 & 3.64 & 12.40 & 8.91 \\
\hline MV03 & Direct & 2017 & 97.00 & 97.00 & 95.00 & 78,00 & 98.25 & 84.50 & 7.67 & 1.16 & 7.95 & 1.19 & 10.60 & 4.28 & 12.70 & 8.39 \\
\hline MV04 & Direct & 2011 & 95.00 & 94.00 & 74.00 & 67,00 & 76.00 & 78.00 & 2.95 & 0.55 & 1.80 & 0.50 & 6.75 & 2.39 & 10.30 & 8.11 \\
\hline MV04 & Direct & 2016 & 94.00 & 96.00 & 94.00 & 73,00 & 93.25 & 95.25 & 7.27 & 1.23 & 7.25 & 0.99 & 9.43 & 5.24 & 11.60 & 11.76 \\
\hline MV04 & Direct & 2017 & 94.00 & 96.00 & 94.00 & 77,00 & 100.00 & 86.75 & 3.62 & 0.83 & 5.95 & 0.81 & 5.95 & 3.56 & 10.95 & 9.21 \\
\hline MV05 & Direct & 2014 & 98.00 & 98.00 & 77.00 & 75,50 & 95.50 & 82.00 & 4.38 & 1.40 & 1.12 & 1.15 & 7.07 & 3.71 & 8.76 & 6.56 \\
\hline \multirow[t]{2}{*}{ MV05 } & Direct & 2017 & 100.00 & 99.00 & 59.00 & 56,00 & 99.50 & 93.00 & 4.10 & 2.08 & 1.05 & 1.33 & 8.70 & 4.90 & 9.80 & 7.16 \\
\hline & \multicolumn{2}{|c|}{$\mathbf{L S D}_{\mathbf{5} \%}$} & ns & ns & ns & ns & 21.40* & ns & ns & $0.55 * * *$ & 3.63** & $0.46 * * *$ & ns & $1.66 * * *$ & ns & $1.45 * * *$ \\
\hline $\begin{array}{l}\text { MV06 } \\
\text { MV06 }\end{array}$ & $\begin{array}{l}\text { Direct } \\
\text { Direct }\end{array}$ & $\begin{array}{l}2013 \\
2017 \\
\end{array}$ & $\begin{array}{r}72.00 \\
97.00 \\
\end{array}$ & No Data & $\begin{array}{l}19.00 \\
59.00 \\
\end{array}$ & No Data & $\begin{array}{l}63.00 \\
94.00 \\
\end{array}$ & No Data & $\begin{array}{l}1.01 \\
3.13 \\
\end{array}$ & No Data & $\begin{array}{l}0.72 \\
2.15 \\
\end{array}$ & No Data & $\begin{array}{l}5.55 \\
3.85 \\
\end{array}$ & No Data & $\begin{array}{l}3.20 \\
3.78 \\
\end{array}$ & No Data \\
\hline $\begin{array}{l}\text { MV07 } \\
\text { MV07 } \\
\end{array}$ & $\begin{array}{l}\text { Direct } \\
\text { Direct }\end{array}$ & $\begin{array}{l}2013 \\
2017 \\
\end{array}$ & $\begin{array}{l}87.00 \\
98.00 \\
\end{array}$ & No Data & $\begin{array}{l}16.00 \\
85.00 \\
\end{array}$ & No Data & $\begin{array}{l}54.00 \\
95.00 \\
\end{array}$ & No Data & $\begin{array}{l}0.76 \\
3.42 \\
\end{array}$ & No Data & $\begin{array}{r}0.44 \\
1.38 \\
\end{array}$ & No Data & $\begin{array}{l}3.27 \\
6.63 \\
\end{array}$ & No Data & $\begin{array}{r}2.85 \\
6.55 \\
\end{array}$ & No Data \\
\hline MV07 & \multicolumn{2}{|c|}{$\mathbf{L S D}_{\mathbf{5} \%}$} & $14.17 *$ & & $25.55 * *$ & & $25.30 *$ & & $1.75 * *$ & & 0.91* & & 3.24* & & $3,29 *$ & \\
\hline
\end{tabular}


International Journal of Agriculture, Environment and Bioresearch

Vol. 5, No. 02; 2020

ISSN: $2456-8643$

Table 3 .Effect of genotype, length ofstorage time and seed dressing with fludioxonil + metalaxil-M on the characters (Keszthely and Martonvásár, 2019)

\begin{tabular}{|c|c|c|c|c|c|c|}
\hline \multirow[b]{2}{*}{ Hybrid } & \multirow[b]{2}{*}{$\begin{array}{l}\text { Dressing } \\
\text { type }\end{array}$} & \multirow[b]{2}{*}{$\begin{array}{c}\text { Storing } \\
\text { year }\end{array}$} & \multicolumn{2}{|c|}{ Keszthely (2019) } & \multicolumn{2}{|c|}{ Martonvásár (2019) } \\
\hline & & & $\begin{array}{c}\text { Yield } \\
\text { (kg/plot) }\end{array}$ & $\begin{array}{c}\text { Seed } \\
\text { moisture } \\
\text { content }(\%)\end{array}$ & $\begin{array}{c}\text { Yield } \\
\text { (kg/plot) }\end{array}$ & $\begin{array}{c}\text { Seed } \\
\text { moisture } \\
\text { content }(\%)\end{array}$ \\
\hline \multirow{3}{*}{ MV01 } & \multirow{16}{*}{$\begin{array}{l}\text { fludioxonil + } \\
\text { metalaxil-M }\end{array}$} & 2011 & 10.24 & 21.25 & 11.51 & 24.26 \\
\hline & & 2013 & 9.55 & 21.33 & 11.17 & 24.51 \\
\hline & & 2015 & 9.64 & 21.63 & 10.92 & 24.55 \\
\hline \multirow{3}{*}{ MV02 } & & 2012 & 11.26 & 21.55 & 9.61 & 26.90 \\
\hline & & 2013 & 9.35 & 21.45 & 9.64 & 27.02 \\
\hline & & 2015 & 11.29 & 21.73 & 10.16 & 25.82 \\
\hline \multirow{3}{*}{ MV03 } & & 2013 & 10.84 & 19.10 & 9.89 & 21.90 \\
\hline & & 2016 & 9.74 & 19.03 & 9.77 & 22.35 \\
\hline & & 2017 & 11.17 & 18.80 & 10.31 & 21.77 \\
\hline \multirow{3}{*}{ MV04 } & & 2011 & 8.22 & 19.23 & 9.23 & 22.61 \\
\hline & & 2016 & 11.23 & 19.88 & 10.63 & 21.43 \\
\hline & & 2017 & 10.37 & 19.58 & 11.57 & 22.26 \\
\hline \multirow{4}{*}{ MV05 } & & 2014 & 10.40 & 21.48 & 10.08 & 24.50 \\
\hline & & 2016 & 9.87 & 20.92 & 7.36 & 23.95 \\
\hline & & 2017 & 11.96 & 21.75 & 9.76 & 23.65 \\
\hline & & $L S D_{5 \%}$ & $2.08 *$ & $n s$ & $2.26^{*}$ & $n s$ \\
\hline \multirow{2}{*}{ MV06 } & \multirow{5}{*}{$\begin{array}{l}\text { fludioxonil + } \\
\text { metalaxil-M }\end{array}$} & 2014 & 10.26 & 19.22 & \multirow{5}{*}{\multicolumn{2}{|c|}{ No Data }} \\
\hline & & 2017 & 13.59 & 19.38 & & \\
\hline \multirow{3}{*}{ MV07 } & & 2014 & 12.04 & 20.42 & & \\
\hline & & 2017 & 14.28 & 20.57 & & \\
\hline & & $L S D_{5 \%}$ & $2,42 * *$ & $n s$ & & \\
\hline
\end{tabular}


Table 4 .Effect of genotype, length of storage time and seed dressing with fludioxonil + tiabendazol + metalaxil-M + azoxistrobinon the characters (Keszthely,2019)

\begin{tabular}{|c|c|c|c|c|}
\hline \multirow[b]{2}{*}{ Hybrid } & \multirow[b]{2}{*}{ Dressing type } & \multirow[b]{2}{*}{$\begin{array}{c}\text { Storing } \\
\text { year }\end{array}$} & \multicolumn{2}{|c|}{ Keszthely (2019) } \\
\hline & & & Yield (kg/plot) & $\begin{array}{c}\text { Seed } \\
\text { moisture }\end{array}$ \\
\hline & \multirow{16}{*}{$\begin{array}{c}\text { fludioxonil + } \\
\text { tiabendazol + } \\
\text { metalaxil-M + } \\
\text { azoxistrobin }\end{array}$} & 2011 & 10.48 & 20.43 \\
\hline MV01 & & 2013 & 10.05 & 19.98 \\
\hline & & 2015 & 10.72 & 20.20 \\
\hline & & 2012 & 10.60 & 21.78 \\
\hline MV02 & & 2013 & 11.42 & 21.18 \\
\hline & & 2015 & 10.70 & 21.13 \\
\hline & & 2013 & 11.02 & 18.83 \\
\hline MV03 & & 2016 & 10.04 & 18.88 \\
\hline & & 2017 & 11.35 & 18.58 \\
\hline & & 2011 & 8.98 & 19.45 \\
\hline MV04 & & 2016 & 10.79 & 19.78 \\
\hline & & 2017 & 10.04 & 19.28 \\
\hline \multirow{4}{*}{ MV05 } & & 2014 & 10.40 & 20.38 \\
\hline & & 2016 & 10.28 & 20.86 \\
\hline & & 2017 & 10.34 & 20.94 \\
\hline & & $L S D_{5 \%}$ & $0,81 *$ & \\
\hline
\end{tabular}

Table 5. Effect of seed storing period on the characters examined, averaged over genotypes and seed dressing (Martonvásár, 2019)

\begin{tabular}{|c|c|c|c|c|}
\hline \multirow[b]{2}{*}{ Examined characters } & \multicolumn{3}{|c|}{ Seed storing period } & \multirow[b]{2}{*}{$L S D_{5 \%}$} \\
\hline & $\begin{array}{l}\text { The longest } \\
\text { storage time }\end{array}$ & $\begin{array}{c}\text { Middle storage } \\
\text { time }\end{array}$ & $\begin{array}{l}\text { The shortest } \\
\text { storage time }\end{array}$ & \\
\hline Rotten seeds (pc) & 5.80 & 3.60 & 4.40 & $0.97 * * *$ \\
\hline Root lenght (cm) & 7.52 & 8.49 & 8.32 & $0.65 * *$ \\
\hline Plant number (pc) & 51.48 & 52.85 & 54.00 & $1.23 * * *$ \\
\hline $\begin{array}{c}\text { Stage of BBCH } 14 \\
\text { (days) }\end{array}$ & 25.45 & 23.83 & 23.65 & $0.55^{* * *}$ \\
\hline $\begin{array}{c}\text { Plant number before } \\
\text { harvesting }(\mathrm{pc})\end{array}$ & 51.63 & 52.43 & 53.95 & $1.30 * *$ \\
\hline Yield (kg/plot) & 10.41 & 10.27 & 10.78 & $0.36^{*}$ \\
\hline
\end{tabular}

